\title{
Primary productivity of the phytoplankton in a tropical Brazilian shallow lake: experiments in the lake and in mesocosms
}

Produtividade primária em um lago tropical raso brasileiro: experimentos no lago e em mesocosmos

\author{
Eliana Garcia Feresin ${ }^{1}$, Marlene Sofia Arcifa ${ }^{1}$,
}

Lúcia Helena Sampaio da Silva ${ }^{2}$ and André Luiz Henríques Esguícero ${ }^{1}$

\author{
${ }^{1}$ Departamento de Biologia, Universidade de São Paulo - USP, \\ Av. Bandeirantes, 3900, CEP 14040-901, Ribeirão Preto, SP, Brazil \\ e-mail: eliana-gf@uol.com.br; marcifa@usp.br; andre.esguicero@gmail.com
}
${ }^{2}$ Laboratório de Ficologia, Departamento de Botânica, Museu Nacional, Universidade Federal do Rio de Janeiro - UFRJ, Quinta da Boa Vista, s/n, São Cristóvão, CEP 20940-040, Rio de Janeiro, RJ, Brazil e-mail: luciahssilva@gmail.com

\begin{abstract}
Aim: To evaluate the primary productivity of the phytoplankton in the Lake Monte Alegre, southeastern Brazil, and the factors that influence its fluctuations, experiments were carried out in the lake and in mesocosm; Methods: Primary productivity rates were measured using the ${ }^{14} \mathrm{C}$ technique, in experiments carried out monthly in the lake, during one year, and in two mesocosm experiments, one in the winter and another in the summer. Other factors also analyzed were temperature, dissolved oxygen, $\mathrm{pH}$, electrical conductivity, chlorophyll- $a$, alkalinity, nutrients, and nitrogen limitation. Hypotheses on the influence of grazing and excretion by zooplankton and fish on phytoplankton properties were tested in two mesocosm experiments; Results: Higher PP in the water column of the lake occurred in the transition periods, when thermal stratification is unstable, and lower PP in the cool season (frequent mixing) and in mid-summer (more stable stratification). The limiting factor in the cool season seems to be mainly temperature and in mid-summer lower light intensities, due to higher rainfall and overcast, $\mathrm{N}$ limitation and physical disturbances caused by storms. PP was not influenced by the zooplankton in the experiment I, despite the effect of grazing on other phytoplankton properties. The excretion by the phytoplanktivorous fish (adults of Tilapia rendalli) enhanced PP in the experiment II, outweighing grazing on the phytoplankton; Conclusions: We suppose that the preponderant factors which affected primary productivity in the lake were physical and chemical ones, biotic factors having a secondary role. The thermal behavior of the lake, which is warm discontinuous polymictic, governs nutrient losses and releases, influencing PP in addition to other factors related to seasons.
\end{abstract}

Keywords: primary productivity, assimilation rates, chlorophyll- $a$, thermal behavior, bottom-up and top-down control.

Resumo: Objetivo: Para avaliar a produtividade primária do fitoplâncton e os fatores que influenciam suas flutuaçôes foram feitos experimentos no Lago Monte Alegre e em mesocosmos; Métodos: Foram feitos experimentos mensais de produtividade primária (PP), usando o método do ${ }^{14} \mathrm{C}$, no lago, durante um ano, e em dois experimentos em mesocosmos, um no inverno e outro no verão. Outros fatores medidos foram temperatura, oxigênio dissolvido, $\mathrm{pH}$, condutividade elétrica, clorofila- $a$, alcalinidade, nutrientes e limitaçáo de nitrogênio. Foram testadas hipóteses sobre a influência do consumo e excreção do zooplâncton e peixes sobre o fitoplâncton em dois experimentos realizados em mesocosmos; Resultados: Maior PP na coluna de água do lago ocorreu nos períodos de transição, quando a estratificação é instável, e menor PP na estação fria (circulação freqüente) e no meio do veráo (estratificação mais estável). O fator limitante na estaçáo fria parece ser principalmente a temperatura e no meio do verão as intensidades luminosas mais baixas, devido a maior pluviosidade e tempo nublado, limitação de nitrogênio e perturbaçōes físicas causadas por tempestades. PP não foi influenciada pelo zooplâncton no experimento I, apesar do efeito do consumo sobre outros atributos do fitoplâncton. A excreção pelo peixe fitoplanctófago (adultos de Tilapia rendalli) causou o aumento da PP no experimento II, superando o consumo do fitoplâncton; Conclusóes: Nós supomos que os fatores preponderantes que afetam a produtividade primária no lago são físicos e químicos, tendo os fatores bióticos um papel secundário. O comportamento térmico do lago, que é polimíctico descontínuo quente, controla a perda e liberação de nutrientes, influenciando a produtividade primária além de outros fatores relacionados às estaçóes do ano.

Palavras-chave: produtividade primária, taxas de assimilação, clorofila- $a$, comportamento térmico, controle ascendente ou descendente. 


\section{Introduction}

Primary productivity fluctuations in temperate lakes are more clearly defined and connected to seasons than in the tropics. Primary production can be much higher in tropical lakes due to the direct effect of the temperature, under nutrient saturation (Lewis, 1996), reaching values 2 to 3 times higher than in temperate lakes (Lewis, 1996; Amarasinghe and Vijverberg, 2002). The complex dynamics of the mixed layer and the higher metabolic rates in tropical lakes speed up the return of nutrients to the euphotic zone (Lewis, 1996). General processes in lakes of higher latitudes, where studies have started earlier, are better known than in the tropics. Most of the first studies in tropical limnology have been carried out in African and Indonesian lakes (e.g. Beadle, 1932; Ruttner, 1931, 1952; Worthington, 1931; Worthington and Ricardo, 1936; complete historical background can be found in the reviews by Beadle, 1974 and Talling and Lemoalle, 1998).

Studies on primary productivity of phytoplankton in Brazilian freshwaters have been carried out in reservoirs, a few natural lakes, and floodplain lakes (e.g. Barbosa and Tundisi, 1980; Barbosa et al., 1989; Calijuri et al., 1999; Calijuri and Dos Santos, 2001; Feresin, 1994; Fisher, 1979; GianesellaGalvão 1985; Henry, 1993; Henry et al., 1998, 2006; Nishimura et al., 2008; Petrucio and Barbosa, 2004; Petrucio et al., 2006; Rahaingomanana et al., 2002; Roland, 2000; Schmidt, 1973; Toledo and Hay, 1988; Tundisi et al., 1981, 1997).

The basic controlling factors of primary production are light and nutrients, varying their relative importance in the ecosystems according to their dynamics. Phytoplankton losses in reservoirs, related to flows diverted to turbines and spillways, should also be considered (Calijuri et al., 1999). Some reservoirs, however, resemble lakes, owing to their high residence times, as for instance Jurumirim (334 days) (Henry et al., 2006) and Paraibuna (800 days) (Arcifa et al., 1981). However, the reservoirs with low residence time, particularly the "run-of-the-river" dams, are closer to lotic water bodies. The internal processes in floodplain lakes are related to the river dynamics, whose influence can vary depending on the connection lake-river. However, the allochthonous contribution of sediments and nutrients plays an important role in all the water bodies. Primary production can be influenced by the joint action of flood pulses and anthropic activities, as in the Amazonian floodplain Lake Batata, impacted by bauxite tailings (Roland et al., 1997; Roland, 2000).
Shallow and deep lakes function in distinct ways regarding nutrient regeneration and light penetration. The intuitive idea on tropical shallow lakes drives to conclusions that factors such as nutrients and temperature are suitable for production along the year. However, the definition of shallow lake is not so easy (Scheffer, 2004; Padisák and Reynolds, 2003), as well as the establishment of the depth limit. Functionally, a shallow lake is prone to frequent mixing and sediment resuspension (Padisák and Reynolds, 2003) in contrast with deep lakes, where stratification periods can be long enough to influence the whole community and processes such as photosynthesis.

This study was carried out during a year in a shallow reservoir that functions as a lake. Differing from the continuous polymictic type, it does not circulate every day. Experiments on primary productivity were made in the lake and in two mesocosm experiments that tested the effect of grazing and nutrient excretion by the zooplankton and fish on the phytoplankton properties. The chlorophyll- $a$, alkalinity, and assimilation rates were also evaluated. Profiles of temperature, dissolved oxygen, $\mathrm{pH}$, and electrical conductivity were obtained during the productivity experiments, as well as measurements of nutrient concentrations and nitrogen limitation on some occasions.

The aim of this study was to evaluate the primary productivity in the Lake Monte Alegre and the factors that influence its fluctuations. The hypotheses were that features connected to its shallowness and the abiotic factors play a major role in the phytoplankton production.

\subsection{Study area}

Lake Monte Alegre ( $21^{\circ} 10^{\prime} 04^{\prime \prime} S$ and $47^{\circ} 51^{\prime} 28^{\prime \prime}$ W, updated by GPS) is a small, shallow, eutrophic, and warm discontinuous polymictic reservoir located in Ribeirão Preto, State of São Paulo (Figure 1) (area 7 ha, $\mathrm{Z}$ max. = $5 \mathrm{~m}, \mathrm{z}=2.9 \mathrm{~m}$ ). Macrophytes are not abundant and are distributed in discrete small stands along the margins, occurring in higher densities in the area of the creek inflow. The margins are protected by dense vegetation composed of trees and grass. Located in southeastern Brazil, at an altitude of $500 \mathrm{~m}$, the lake resulted from damming Laureano Creek, which belongs to the Pardo River basin, in 1942. It can stratify for relatively long periods in the warm season, leading to oxygen depletion near the bottom (Arcifa et al., 1990). As the outlet is superficial and the dam is not manipulated, it functions as a small lake, with a retention time of ca. 45 days, during the period between the wet and 


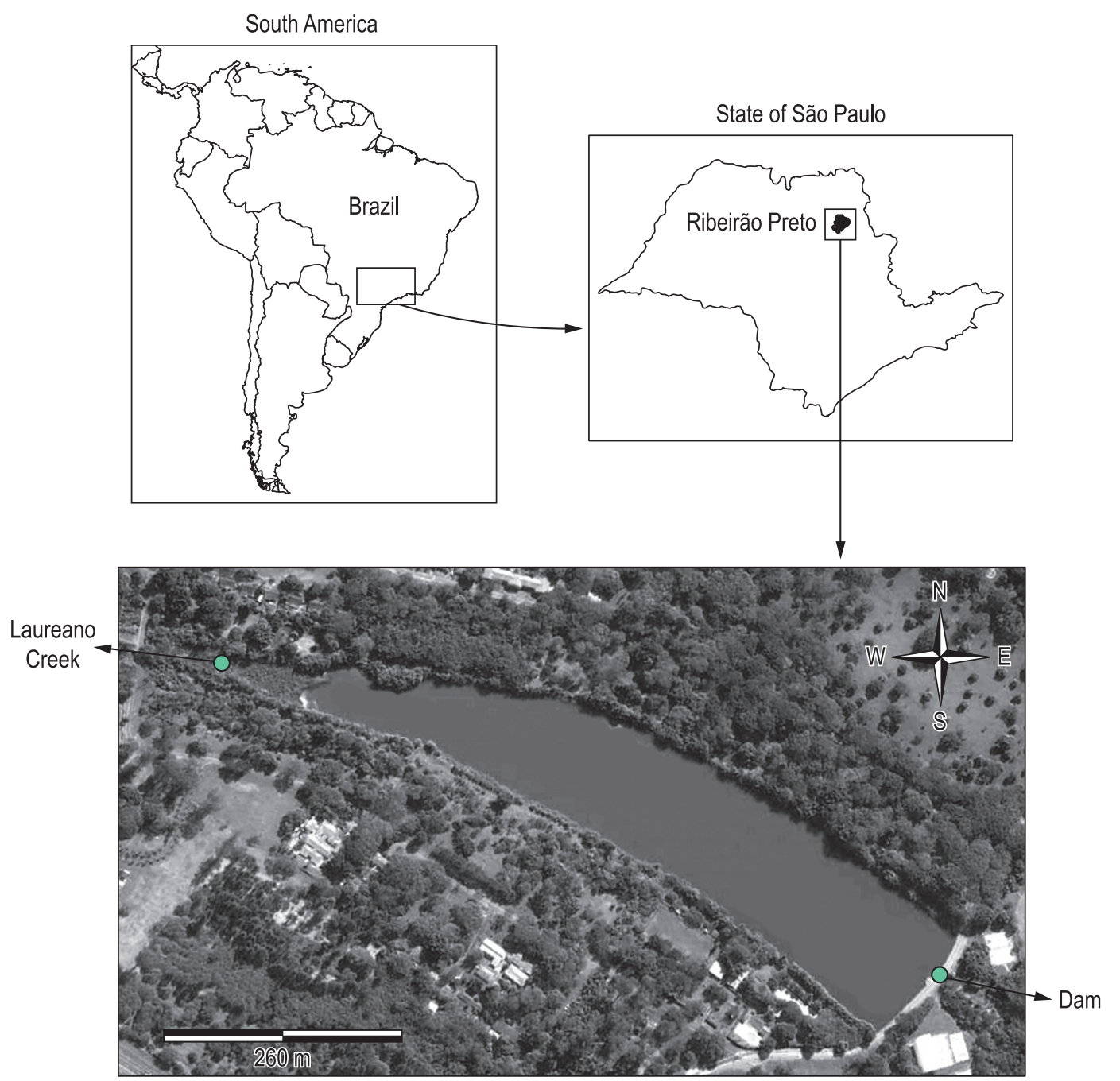

Figure 1. Location of Lake Monte Alegre in Brazil, and a satellite photo of the lake.

dry seasons. Currently, it is ornamental and used for research and teaching. According to Nimer (1989), the region has a tropical semi-humid climate, with a defined cool-dry season (May-September) and a warm-wet one (October-April).

Based on climatic features and the lake thermal behavior, four periods were identified (Arcifa et al., 1998): A. January-March, warm-wet with more stable stratification; B. April, a transition period in the end of the warm-wet period, with unstable stratification; C. May-August, cool-dry with more frequent circulation; D. September-December, transition period between the warm-dry and warmwet periods, with unstable stratification.

\section{Material and Methods}

\subsection{Primary productivity in the lake}

Experiments on primary productivity were carried out monthly (except October), at a station located at the deepest central area of the lake, from August 1998 to July 1999, in four depths, according to the light penetration. The ${ }^{14} \mathrm{C}$ method was used, following procedures and calculations according to Wetzel and Likens (1991).

Water samples were collected with a Ruttner bottle, in the layers of $50,25,10$, and $1 \%$ of incident light, measured with a Licor-250 photometer. Due to strong inhibition of the productivity in the surface layer, observed in a preliminary survey, and the proximity to the $50 \%$ layer, the first was excluded from this study. Two transparent bottles and one dark bottle, to which $1 \mathrm{ml}$ of $\mathrm{NaH}^{14} \mathrm{CO}_{3}$ (7.34 $\mu \mathrm{Ci} . \mathrm{mL}^{-1}$; Amersham PLC, UK) was added, were incubated in situ in each depth, for 3 hours, in the morning. An additional dark bottle was taken in each depth for inorganic carbon measurement using the alkalinity and $\mathrm{pH}$ method (Wetzel and Likens, 1991). The radioisotope activity was evaluated in 
a sample fixed with $1 \%$ formaldehyde before the addition of the radioactive bicarbonate. At the end of the incubation period, samples were filtered at the laboratory, in Millipore filters (HA, $0.45 \mu \mathrm{m}$ ), then dried in a desiccator, their activity being measured using a scintillation counter (Beckman, LS6500), and following the method described by Wetzel and Likens (1991).

Other factors were measured, in the water column, such as temperature and dissolved oxygen (Yellow Springs Inc., model 95), pH (YSI 60), electrical conductivity at $25^{\circ} \mathrm{C}$ (YSI 30), water transparency (30 cm-white Secchi disk), alkalinity (Stumm and Morgan, 1996), and chlorophyll-a (Jeffrey and Humphrey, 1975). The use of Lorenzen's method (1967) for also evaluating phaeopigments was precluded due to the phytoplankton composition in some samples, which invalidated the analyses after the acidification, when a high turbidity biased the spetrophotometric measurements. Dissolved N-NO - (Mackereth et al., 1978), $\mathrm{N}_{-} \mathrm{NH}_{4}^{+}$and $\mathrm{P}_{-} \mathrm{PO}_{4}^{3-}$ (Golterman et al., 1978), and $\mathrm{N}$ limitation were analyzed in the winter of 1998 and in the summer of 1999. Integrated samples of the entire water column were collected using an electrical pump (Jabsco, model 346000000), which delivered $30 \mathrm{~L} \cdot \mathrm{min}^{-1}$.

The assimilation rate was calculated as the ratio between primary productivity rate and chlorophyll- $a$ concentration, in order to evaluate the photosynthetic efficiency.

The nitrogen limitation was analyzed by the ammonium enhancement response (AER), according to Vanni and Layne (1997), values $>1$ indicating $\mathrm{N}$ limitation. Phosphorus limitation was also evaluated using the alcaline phosphatase method, but as it was not sensitive enough results were unreliable and discarded.

Meteorological data were provided by the Institute of Agronomy, located ca. $5 \mathrm{~km}$ from the lake. The wet and dry seasons were determined by a relation between air temperature and rainfall (Gaussen and Bagnouls in Nimer, 1989).

\subsection{Primary productivity in mesocosm experiments}

Two mesocosm experiments were made in the lake, the first in the winter of 1998 (AugustSeptember) and the second during the summer of 1999 (January). The experiment I (winter) lasted 25 days and used the mesocosm closed at the lower end, as described by Arcifa and Guagnoni (2003). The effects of the zooplankton on the phytoplankton properties, including productivity rates, were tested. The treatments (3 replicates each) were: A. with zooplankton, and B. zooplanktonfree. The treatment A contained rotifers, copepods and cladocerans, including larger species, such as Daphnia gessneri and D. ambigua; the treatment B was not totally free of zooplankton and contained a very few rotifer species and individuals, tecnically impossible to be retained on the net $(60 \mu \mathrm{m}$ meshed) located at the mouth of the enclosure. The experiment II (summer) lasted 18 days and tested the effects of the zooplankton and a phytoplanktivorous fish on the phytoplankton with the treatments (3 replicates each): A. zooplankton + fish (1 individual of the adult cichlid fish Tilapia rendalli) and $\mathrm{B}$. zooplankton- and fish-free. In this experiment, the zooplankton was predominantly composed of rotifers in the treatment $A$, and rotifers in lower densities and diversity in B, due to the same reasons explained above. Primary productivity rates, physical and chemical factors, and $\mathrm{N}$ limitation were also measured in both experiments, following the methods already described.

The productivity measurements were made in the layer of $50 \%$ of incident light inside the enclosures and in the lake, at the beginning and end of the experiments. Integrated samples of the water column inside the enclosures for the experiments of $\mathrm{N}$ limitation were collected with the pump.

\subsection{Statistical analysis}

Differences between means of the treatments in both experiments were tested by ANOVA and the post hoc Tukey test (significance level $\mathrm{p} \leq$ 0.05) (Nester and Wasserman, 1974). The Principal Component Analysis (PCA) was used for identifying possible patterns in the monthly distribution of the factors (Peres-Neto et al., 2003) Only the eigenvalues $\geq 1$ were considered in the analysis.

\section{Results}

\subsection{Meteorological data}

Rainfall and temperature data indicated that the warm-wet season lasted from October to April (Figure 2). The maximum air temperatures decreased slightly in the winter (June-September) compared to the other seasons, while the minimum temperatures declined more clearly. The winter nights were cool and the days relatively warm. Winds were usually weak during the year, not exceeding $4 \mathrm{~m} / \mathrm{s}$, with peaks in September-October. 



Figure 2. Meteorological data of the period from August 1998 to July 1999.

The insolation hours decreased during the warm-wet season, particularly from December 1998 to February 1999 (Figure 2), with frequent rains and overcast days.

\subsection{Physical and chemical factors}

Longer or more stable periods of the thermal stratification of the lake, as expected, were observed during the warm season, from December to February, a maximum temperature $\left(28.2^{\circ} \mathrm{C}\right)$ being recorded in January (Figure 3). A tendency for isothermy occurred in August 1998 and from April to July 1999 , the lowest temperature $\left(19.5^{\circ} \mathrm{C}\right)$ occurring in June.

Dissolved oxygen was clearly stratified from November to March, coinciding approximately with the period of more stable thermal stratification (Figure 3). Values lower than $1 \mathrm{mg} . \mathrm{L}^{-1}$ were recorded near the bottom, during summer. Despite the tendency for water circulation during the cool season, oxygen was usually unevenly distributed in the water column. Short periods of thermal stratification were sufficient to cause a slight decrease of oxygen concentrations, particularly near the bottom.

The $\mathrm{pH}$ values varied from 6.2 to 7.4 during the study period. A seasonal variation was not clear, but during periods of stratification, from November to February, the $\mathrm{pH}$ values were heterogeneously distributed in the water column, with higher values near the surface. Conductivity values varied from 56 to $72.6 \mu \mathrm{S} . \mathrm{cm}^{-1}$, indicating the accumulation of ions near the bottom for a short period in the summer.

The alkalinity ranged from 0.12 to 0.97 meq. $\mathrm{L}^{-1}$, the highest values being found in the superficial layers in September and November (Figure 4). The lowest values were recorded in the water column from December to February.

The water transparency ranged from 1.70 to $2.05 \mathrm{~m}$, during the cool-dry season, and was $c a$. $1.50 \mathrm{~m}$, during the warm-wet season (Figure 5). Accordingly, higher values of light intensity, in the water surface, were recorded in the cool seasonbeginning of the warm one. The light attenuation was intense, $50 \%$ of surface light intensity being recorded in the layers of 0.5 to $0.75 \mathrm{~m}$, during the year. In February and March, the light attenuation in the water column was stronger, values lower than 500 lux occurring from 1 to $4 \mathrm{~m}$. The limit of the euphotic zone varied from 3.5 to $4.6 \mathrm{~m}$ during the study period, the lowest values being recorded in the warm-wet season. The values of the ratio Zmax/Zeu (maximum depth/euphotic zone) were 
higher during the summer when the transparency and light intensity values decreased (Figure 5). Higher concentrations of dissolved $\mathrm{P}_{-} \mathrm{PO}_{4}^{3-}$ were found in the summer and $\mathrm{N}_{-} \mathrm{NO}_{3}{ }^{-}$in the winter

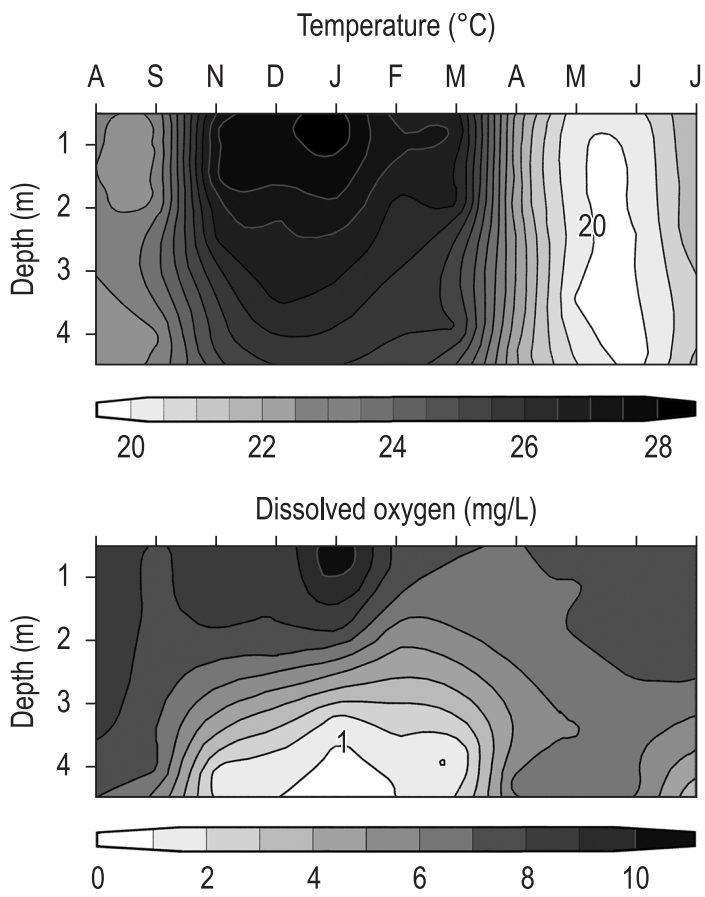

Figure 3. Isopleths of temperature and dissolved oxygen from August 1998 to July 1999.
(Table 1). The concentrations of dissolved N-NH${ }_{4}^{+}$ were higher in the summer (data of treatments in the beginning of the experiment II). There was indication of $\mathrm{N}$ limitation in this season, with AER values above 1 .

\subsection{Primary productivity, chlorophyll-a, and assimilation rates in the lake}

Maximum values of primary productivity (PP) rates were recorded in spring (September to December), and late summer-beginning of autumn (March-April) from surface to 2-3 m (Figure 4). PP rates declined in August and from May to July, during the cool-dry season, and in mid-summer (January-February), particularly in February. The production was limited to the epi-and metalimnion during the summer. PP increased in the water column with relatively high values in deeper layers (3.0-3.5 m), from September to November. In November, from the two peaks of PP in the water column, one corresponded to the layer with $50 \%$ of incident light $(0.75 \mathrm{~m})$, and the other to the $10 \%$ layer $(2.5 \mathrm{~m})$. The productivity rates per area highlighted the highest value in November and the lowest in August (Figure 6).

Higher concentrations of chlorophyll-a were found in spring-early summer (September-January) and in autumn-winter (April-July) (Figure 4).

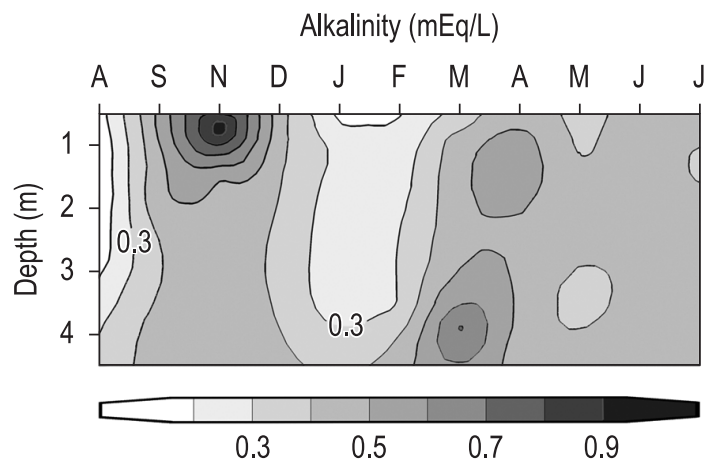

Phytoplankton productivity $\left(\mathrm{mgC} / \mathrm{m}^{3} / \mathrm{h}\right)$
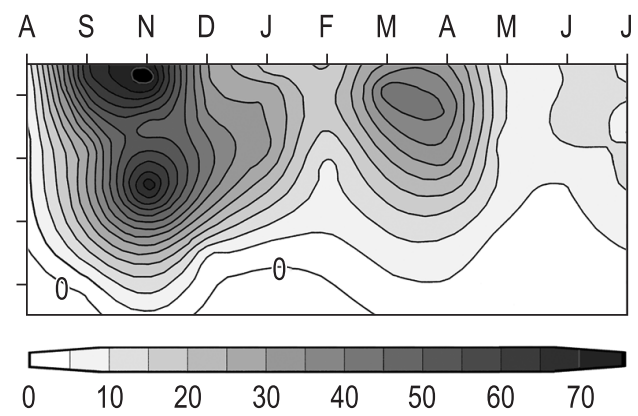

Chlorophyll-a ( $\mu \mathrm{g} / \mathrm{L})$

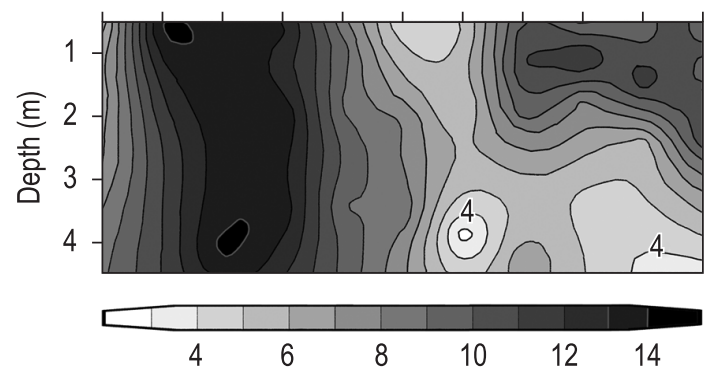

Assimilation (mgC/mgChl-a/h)
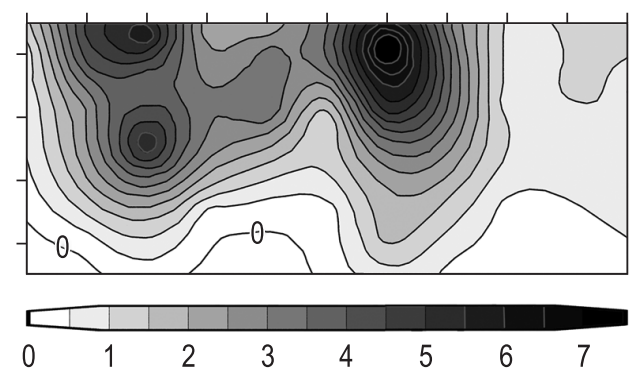

Figure 4. Isopleths of primary productivity rates, chlorophyll- $a$ concentrations, assimilation rates, and alkalinity, from August 1998 to July 1999. 




Figure 5. Fluctuations of Secchi disk transparency (SD), light intensities at the water surface, hours of insolation, and Zmax/Zeu, from August 1998 to July 1999.

Table 1. Temperature, light intensities, nutrients (N, P), N limitation (NL), primary productivity rates (PP), and chlorophyll- $a$ concentrations in the mesocosm experiments. Different letters indicate significant differences (post hoc Tukey test, $\mathrm{p}<0.05)$.

\begin{tabular}{|c|c|c|c|c|c|c|c|c|c|}
\hline \multicolumn{10}{|c|}{ Experiment I - August-September 1998} \\
\hline & & $T$ & Light & $\mathrm{N}-\mathrm{NH}_{4}^{+}$ & $\mathrm{N}^{-\mathrm{NO}_{3}^{-}}$ & $\mathrm{P}_{-} \mathrm{PO}_{4}^{3-}$ & $\mathrm{NL}$ & PP & Chl-a \\
\hline & & $\left({ }^{\circ} \mathrm{C}\right)$ & (Lux) & $\left(\mu g \cdot L^{-1}\right)$ & $\left(\mu g . L^{-1}\right)$ & $\left(\mu g . L^{-1}\right)$ & (AER) & $\left(\mathrm{mgC} \cdot \mathrm{m}^{-3} \cdot \mathrm{h}^{-1}\right)$ & $\left(\mu g . L^{-1}\right)$ \\
\hline \multirow[t]{3}{*}{ Start } & A & 22.5 & & 60 (a) & 671 (a) & 38 (a) & $0.83(\mathrm{a})$ & $13.2(\mathrm{a})$ & 12.6 (a) \\
\hline & B & 22.5 & 9442 & 90 (a) & 844 (a) & 33 (a) & $0.81(\mathrm{a})$ & 6.8 (a) & $5.2(\mathrm{~b})$ \\
\hline & Lake & 22.0 & 10694 & 55 & 988 & 33 & 0.65 & 10.3 & 11.9 \\
\hline \multirow[t]{3}{*}{ End } & A & 22.8 & 7606 (a) & 35 (a) & 333 (a) & 61 (a) & $0.84(\mathrm{a})$ & 30.9 (a) & 8.8 (a) \\
\hline & B & 22.6 & 6884 (a) & 38 (a) & 463 (a) & 46 (a) & $0.82(\mathrm{a})$ & 25.1 (a) & 7.8 (a) \\
\hline & Lake & 22.8 & 10766 & 60 & 563 & 28 & 0.86 & 34.6 & 12.8 \\
\hline \multicolumn{10}{|c|}{ Experiment II - January 1999} \\
\hline \multirow[t]{3}{*}{ Start } & A & 27.9 & $21408(a)$ & $659.3(a)$ & $103.3(a)$ & $126.7(\mathrm{a})$ & $2.8(a)$ & 24.1 (a) & $10.9(a)$ \\
\hline & B & 27.4 & 14445 (a) & 671.3 (a) & 110.0 (a) & 126.0 (a) & 3.8 (a) & 14.3 (a) & $12.6(\mathrm{a})$ \\
\hline & Lake & 27.9 & 23410 & & 178.0 & 96.0 & 1.7 & 20.8 & 10.7 \\
\hline \multirow[t]{3}{*}{ End } & A & 27.6 & $18300(a)$ & 929 & 96.0 (a) & 99.7 (a) & $3.8(a)$ & $40.6(a)$ & $30.2(a)$ \\
\hline & B & 27.5 & $12137(b)$ & & $100.3(a)$ & $166.7(a)$ & $5.1(a)$ & $7.2(b)$ & $8.2(b)$ \\
\hline & Lake & 27.5 & 17721 & & 302.0 & 68.0 & 2.4 & 17.0 & 12.1 \\
\hline
\end{tabular}

The concentrations decreased in February-March, during the summer. High concentrations of chlorophyll- $a$ were recorded near the bottom in November. However, part of the chlorophyll- $a$ could be composed of phaeopigments as they were not separated from the active chlorophyll- $a$, and could explain the high values in the aphotic zone.

Mid-autumn and winter (May-August) were marked by the lowest productivity and assimilation rates, despite relatively high chlorophyll-a concentrations (Figure 4). Mid-summer (January-
February) was a period of intermediate productivity and assimilation rates.

\subsection{Experiments of primary productivity and $N$ limitation in mesocosm}

PP rates were not significantly different in both treatments at the end of the experiment I (Table 1). The light intensities were similarly high in both treatments, and other physical and chemical features did not differ between the treatments. There was no indication of $\mathrm{N}$ limitation (AER values $<1$ ) in both treatments and in the lake. 
At the end of the experiment II, PP rate was significantly higher $(\mathrm{p}=0.013)$ in the treatment A (zooplankton + fish) than in the treatment $B$ (zoo- and fish-free) (Table 1). Light intensity was lower in the treatment $B$ than in $A(p=0.05)$. There was indication of a strong $\mathrm{N}$ limitation in both treatments, which was a little lower in the lake.

\subsection{Principal component analysis}

The principal components analysis (PCA) reduced the variation of six variables (alkalinity, primary productivity, chlorophyll-a, assimilation, Zmax/Zeu ratio and temperature) to two principal components, $\mathrm{PC} 1$ and $\mathrm{PC} 2$, which explained 47 and $42.9 \%$ of the total variance, respectively (Table 2). The loading values obtained by PCA correspond to the coefficients of correlation of each variable with each component. Indirectly, these values also indicate the relationship between the original variables. The variables PP, chlorophyll- $a$ and temperature were highly correlated with the PC1, and the variables alkalinity, assimilation and $\mathrm{Zmax} /$ Zeu ratio were highly correlated with the PC2.

Based on the PC1 axis, of the PC1 and PC2 plot (Figure 7), it was possible to discriminate the months composing the cool-dry season (AprilSeptember) from those of the warm-wet season (November-March). Analyzing the PC1 and PC2 plot, the formation of 4 groups of months was evident. One group is composed of November, which presented the highest productivity rates (Figure 4), and May to August, another group, with the lowest PP values. December to February is a group with the highest temperatures (Figure 2), and March, April, and September is a group belonging to a transition thermal period of relatively high productivity (Figure 4).

\section{Discussion}

The PP rates in Lake Monte Alegre (LMA) are relatively high, approaching the lake to Brazilian meso- to eutrophic water bodies. The maximum values found in Salto Grande Reservoir (Americana) (Calijuri et al., 1999) and LMA are similar $\left(200 \mathrm{mgC} \cdot \mathrm{m}^{-2} \cdot \mathrm{h}^{-1}\right)$. Its average PP rate $\left(77 \mathrm{mgC} \cdot \mathrm{m}^{-2} \cdot \mathrm{h}^{-1}\right)$ is much higher than those of nine of the ten reservoirs studied by Gianesella-Galvão (1985), which are mesotrophic or oligotrophic (Paraibuna), and that of the oligotrophic Jurumirim Reservoir (Henry et al., 2006). PP rates of LMA are near values found in Rio Grande branch of Billings Reservoir (Nishimura et al., 2008), and Promissão Reservoir (Tundisi et al. 1993), but lower than values of Barra Bonita Reservoir (Calijuri and Dos Santos, 2001).

Shallow lakes can be more productive than the deep ones, except those with dense stands of macrophytes (Feresin, 1994). The average productivity in Camargo Lake $\left(57.8 \mathrm{mgC} . \mathrm{m}^{-2} \cdot \mathrm{h}^{-1}\right)$, located near the confluence of Jurumirim Reservoir and Paranapanema River, is $c a$. three times that of the reservoir (Henry et al., 2006), and a little lower

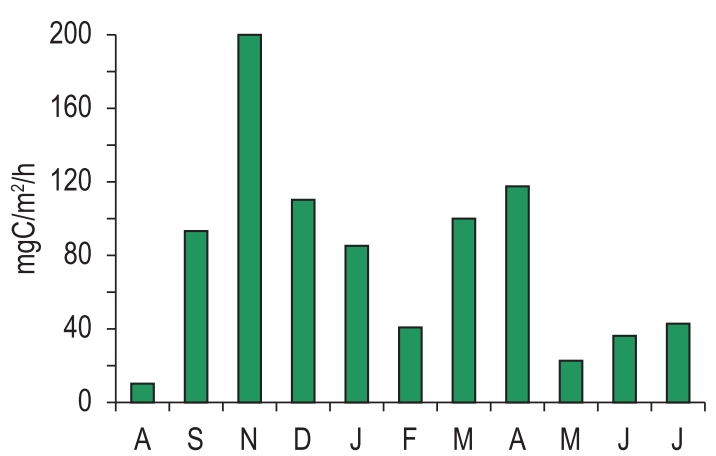

Figure 6. Productivity rates per area, from August 1998 to July 1999.

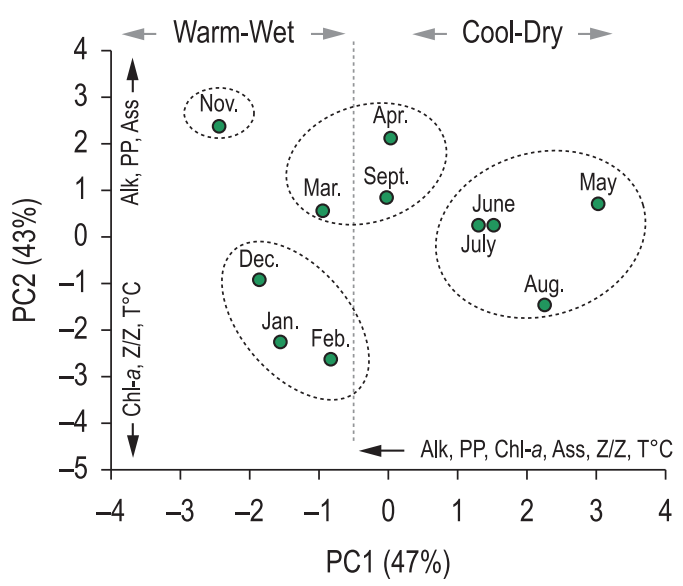

Figure 7. Spatial distribution of the cases' loadings for the principal component (PC) analysis. Z/Z - Zmax/Zeu.

Table 2. Eigenvalues and variables' loadings for the principal component (PC) analysis.

\begin{tabular}{lcc}
\hline \multicolumn{1}{c}{ Variables } & PC1 & PC2 \\
\hline Alkalinity & -0.307046 & 0.857707 \\
Phytoplankton Productivity & -0.817299 & 0.555704 \\
Chlorophyll-a & -0.696486 & -0.567976 \\
Assimilation & -0.600880 & 0.762176 \\
Zmax/Zeu & -0.658578 & -0.710561 \\
Temperature & -0.884836 & -0.352564 \\
\hline Eigenvalues & 2.825066 & 2.577177 \\
\hline
\end{tabular}


than the average PP in Lake Monte Alegre. Lake Carioca ( $\mathrm{Z}$ max. $11.8 \mathrm{~m}$ ) exhibited a much higher PP (2247 $\left.\mathrm{mgC} . \mathrm{m}^{-2} \cdot \mathrm{h}^{-1}\right)$ than Lake D. Helvécio (Z max $32.5 \mathrm{~m}$ ), both warm monomictic (Petrucio and Barbosa, 2004).

The influence of abiotic factors, such as light, temperature, and hydrology is more evident on the temporal fluctuations of productivity rates in the lake, when compared to that of biotic factors.

The temporal and vertical distribution of PP rates is directly or indirectly related to the thermal behavior of the lake. Although the lake circulates irregularly during the year, a period of more stable stratification is evident in the warm-wet season, particularly from December to February. However, deepening of the thermocline, leading to partial mixing, and periods of total mixing can occur during the warm season, characteristic of a polymictic lake (Arcifa et al., 1990). From April to August, circulation can be frequent, when the water column becomes isothermal and, consequently, dissolved oxygen is almost evenly distributed. The production extends to layers deeper than the mixed layer, when the lake is stratified.

In September, in the first period of higher PP, there was no indication of nitrogen limitation and although phosphate concentrations were not so high, they were probably non-limiting. The threshold phosphorus concentration for algae varies from $5 \mu \mathrm{g} . \mathrm{L}^{-1}$ (Reynolds, 1997) to $10 \mu \mathrm{g} . \mathrm{L}^{-1}$ (Sas, 1989), lower than the concentrations found in the lake. This period of high primary productivity, assimilation rates, and chlorophyll-a concentrations coincides with more frequent circulation and unstable stratification, a transition period (Arcifa et al., 1998). The factors favoring the productivity enhancement might be suitable conditions, such as temperature, light intensity, and inorganic carbon. In September, other nutrients $(\mathrm{N}$ and $\mathrm{P}$ ) were non-limiting and although there are no data in November in this study, analyses made in 2001-2002 indicated that concentrations were similar in both months (M. S. Arcifa, unpublished data).

The second period of high PP (March-April) matchs a time of stratification instability and the onset of more frequent mixing, when presumably nutrients trapped in the hypolimnion can be driven to the euphotic zone. Assimilation rates were high and chlorophyll-a concentrations were relatively low, suggesting that the conditions were favorable for a high production, despite the relatively low biomass. Lower rainfall and overcast and increased light intensities, suitable temperatures and inorganic carbon, and probably non-limiting $\mathrm{N}$ and $\mathrm{P}$ concentrations might be the reasons for PP enhancement. Arcifa (1999) reports that N and P concentrations were not particularly low in March and April of 1988, and in 2001-02 (M. S. Arcifa, unpublished data) the same trend was observed.

The distribution and availability of nutrients ( $\mathrm{N}$ and $\mathrm{P}$ ) in the Lake Monte Alegre maintain a close relationship with the thermal behavior of the lake. Forms of nitrogen show a tendency to stratify, during the period of more stable stratification in the warm season, when oxygen is low or depleted near the bottom (Arcifa, 1999). Ammonium accumulates in the hypolimnion and nitrate predominates in the oxygenated epilimnion (Arcifa, 1999). Circulation periods bring ammonium trapped in deeper waters to the oxygenated euphotic zone which, in addition to the contribution from the excretion by organisms, can be assimilated by part of the phytoplankton assemblage, before being nitrified. The phosphorus loss or its release from the sediment connected to the thermal behavior can be expected.

The dynamics of $\mathrm{P}$ in lakes involves a complex interaction with several compounds and ions, by sorption and adsorption (Søndergaard et al., 2003). In the Lake Monte Alegre, due to the iron-rich soil, the iron-bound phosphorus could be responsible for most of the P loss to the sediment, as reported for other shallow lakes (several references in Scheffer, 2004).

As a consequence of the circulation pattern of the lake, both transition periods (early spring and autumn) in between the more stable stratification and circulation periods favor the phytoplankton productivity, contrasting with the other periods, mid-summer, late autumn, and winter. Limiting factors during the summer might be lower light intensities due to increasing overcast, $\mathrm{N}$ limitation, and water turbulence caused by storms. These perturbations not always disrupt stratification but can resuspend sediments mainly from the shallow littoral zone, contributing to the light attenuation in the water. The reduction of the euphotic zone caused mainly by allochthonous suspended solids, owing to high rainfall in the summer, leading to the decline of primary productivity rates, is relatively common in Brazilian reservoirs (Calijuri et al., 1999; Tundisi and Matsumura-Tundisi, 2008).

In late autumn and winter, lower assimilation rates indicate the desacceleration of the photosynthetic process, despite the relatively high chlorophyll- $a$ concentrations. Lower temperatures 
(ca. $20-22{ }^{\circ} \mathrm{C}$ ) might be the major cause, as light penetration in the water column was high. The vertical distribution of PP is clearly related to light attenuation, the deepening of the euphotic layer allowing the photosynthetic process to extend to deeper layers.

In addition to other factors, the effects of hydrological disturbances promoted by high rainfall, storms, and increased water turbulence can be seen in Table 3. It shows accumulated rainfall three days prior to the productivity experiments in the lake, during the summer. The influence of disturbances and increased overcast also collaborated to lower PP rates in January and February. The phytoplankton, expressed as weight and density, also decreased, as well as chlorophyll-a (Figure 4). The recovery of PP rates in March, which was not coincident with increased phytoplankton density and biomass, and chlorophyll- $a$, evidenced a high photosynthetic capacity. However, fluctuations of PP can be expected in between the monthly productivity experiments in the lake and the phytoplankton performance might improve on some occasions during the summer, stimulated by high temperatures. The phytoplankton biomass is not always low in summer in the Lake Monte Alegre, including January and February (Arcifa et al., 1998). Interannual variability in the phytoplankton abundance and processes is common, changing only the hierarchy of causal agents. The intensity of unpredictable events, such as storms, wind fetch, and cold fronts (Arcifa et al., 1990) may vary interannually, affecting the phytoplankton dynamics and production.

In addition to physical aspects (Reynolds, 1989), competition for resources and allelopathy, grazing, and parasitism are important biotic factors in phytoplankton sucession in lakes (Sommer, 1989; Sterner, 1989; Van Donk, 1989; Reynolds, 1997. 2006; Legrand et al., 2003).

The control of biotic factors on phytoplankton properties in the Lake Monte Alegre is not so evident as that of physical and chemical factors.
Silva (2004) concluded that the zooplankton, when composed of efficient filter-feeders such as large cladocerans (Daphnia gessneri and D. ambigua), can exert a top-down effect on the phytoplanton densities and biomasses, thorough herbivory. However, this effect was not evident on the primary productivity rates and chlorophyll-a concentrations in the mesocosm experiment. A secondary role of zooplankton in controlling PP in Jurumirim Reservoir was also suggested by Henry et al. (2006). Hubble and Harper (2000) found that grazing can be a secondary factor as a top-down control on phytoplankton productivity in the African shallow Lake Naivasha, becoming less important with increasing productivity rates and negligible when productivity reaches a very high value $\left(200 \mathrm{mC} \cdot \mathrm{m}^{-3} \cdot \mathrm{h}^{-1}\right)$.

Other evidence that grazing plays a secondary role in controlling phytoplankton properties in the lake is that the low values of the primary productivity and algae abundance, in February 1999, coincided with low densities of planktonic microcrustaceans (cladocerans and copepods) (Fileto, 2001). Low densities of microcrustaceans was also observed in June-July 1999, when PP rates were low. Therefore, it is difficult to attribute the lower PP, in mid-summer and early winter, to a biotic factor such as zooplankton grazing on phytoplankton.

Silva (2004) suggested that the preponderant effect of fish on the phytoplankton was through excretion, a bottom-up control, PP rates increasing in the presence of fish, despite the $\mathrm{N}$ limitation observed.

Grazing by fish is possibly low in the lake because the only planktivore (mostly phytoplanktivore) of the fish fauna are the adults of the exotic cichlid T. rendalli (Arcifa and Meschiatti, 1993, 1996), which occur in relatively low abundance. Filtration rates of Tilapia rendalli in laboratory varied from $0.09 \pm 0.6 .10^{6}$ to $1.66 \pm 0.83 .10^{6}$ algae/weight $(\mathrm{g}) / \mathrm{h}$ (Adriana J. Meschiatti, unpublished data). One fish in each enclosure of the experiment, holding

Table 3. Rainfall and phytoplankton properties during the summer of 1999.

\begin{tabular}{lcccc}
\hline \multicolumn{1}{c}{ Months } & $\begin{array}{c}\text { Accumulated rainfall }(\mathrm{mm}) 3 \\
\text { days prior to PP experiments }\end{array}$ & $\begin{array}{c}\text { Primary productivity } \\
\left(\mathrm{mgC} . \mathrm{m}^{-2} . \mathrm{h}^{-1}\right)\end{array}$ & $\begin{array}{c}\text { Phytoplankton Biomass } \\
\left(\mathrm{mg} . \mathrm{L}^{-1}\right)\end{array}$ & $\begin{array}{c}\text { Phytoplankton Density } \\
\left(\text { ind. } \mathrm{mL}^{-1}\right)\end{array}$ \\
\hline December & 11.1 & 110 & 3.85 & 12597 \\
January & 58.7 & 85 & 1.75 & 4855 \\
February & 75.2 & 40 & 0.60 & 2255 \\
March & 7.8 & 100 & 0.56 & 804 \\
\hline
\end{tabular}

Sources: Silva (2004), this study. 
ca. $2500 \mathrm{~L}$, would consume a maximum of $c$ a. $20 \%$ of the phytoplankton during the experiment, but nutrients introduced by fish excretion enhanced algae growth, outweighing the fish grazing rate (Silva, 2004). The whole fish fauna excretion in the lake might enhance PP, but does not explain its temporal variations.

In summary, our hypotheses were confirmed as evidences point to physical and chemical factors as the preponderant factors influencing the primary production of the phytoplankton in the Lake Monte Alegre. The primary productivity has a close relationship to the thermal behavior of the lake, whose features are connected to its shallowness and low wind strength. We suppose, however, that in between strong physical disturbances and nutrient limitation, biotic factors may act in some periods. Although grazing by zooplankton can be a top-down control on phytoplankton abundance, particularly when larger and more efficient filterfeeders are present, it is a secondary top-down control on productivity. The bottom-up control on productivity by adult $T$. rendalli outweighs the top-down one.

\section{Acknowledgements}

We thank W. Guagnoni for making the mesocosm structure and the laboratory staff for help in the field work. We are grateful to FAPESP for a research grant to MSA (process 97/10407-6) and a postdoctoral grant to EGF (process 97/14681-5), as well as two anonymous referees for valuable suggestions.

\section{References}

AMARASINGHE, PB. and VIJVERBERG, J. 2002. Primary production in a tropical reservoir in Sri Lanka. Hydrobiologia, vol. 487, p. 85-93. http:// dx.doi.org/10.1023/A:1022985908451

ARCIFA, MS. 1999. Lago Monte Alegre: uma visão sobre a estrutura e hipóteses de funcionamento. In HENRY, R., ed. Ecologia de reservatórios: estrutura, função e aspectos sociais. Botucatu: Fundibio/Fapesp. p. 55-76.

ARCIFA, MS. and GUAGNONI, W. 2003. A new model of enclosure for lentic water experiments. Acta Limnologica Brasiliensia, vol. 15, no. 1, p. 75-79.

ARCIFA, MS. and MESCHIATTI, AJ. 1993. Distribution and feeding ecology of fishes in a Brazilian reservoir: Lake Monte Alegre. Interciencia, vol. 18, no. 6, p. 302-313.

ARCIFA, MS. and MESCHIATTI, AJ. 1996. Tilapia rendalli in the Lake Monte Alegre, a case of planktivory. Acta Limnologica Brasiliensia, vol. 8, p. 221-229.

ARCIFA, MS., FROEHLICH, CG. and GIANESELLAGALVÂO, SMF. 1981. Circulation patterns and their influence on physico-chemical and biological conditions in eight reservoirs in Southern Brazil. Verhandlungen der Internationale Vereinigung für Limnologie, vol. 21, p. 1054-1059.

ARCIFA, MS., MESCHIATTI, AJ. and GOMES, EAT. 1990. Thermal regime and stability of a tropical shallow reservoir: Lake Monte Alegre, Brazil. Revue d'Hydrobiologie Tropicale, vol. 23, p. 271-281.

ARCIFA, MS., SILVA, LHS. and SILVA, MHL. 1998. The planktonic community in a tropical Brazilian reservoir: composition, fluctuations and interactions. Revista Brasileira de Biologia, vol. 58, p. 241-254.

BARBOSA, FAR. and TUNDISI, JG. 1980. Primary production of phytoplankton and environmental characteristics of a shallow quaternary lake at Eastern Brazil. Archiv für Hydrobiologie, vol. 90, p. 139-161.

BARBOSA, FAR., TUNDISI, JG. and HENRY, R. 1989. Diel variations in a shallow tropical Brazilian lake. II. Primary production, photosynthetic efficiency and chlorophyll-a content. Archiv für Hydrobiologie, vol. 116 , p. 435-448.

BEADLE, LC. 1932. Scientific results of Cambridge Expedition to the East Asfrican, 1930-1. 4. The waters of some East African lakes in relation to their fauna and flora. Journal of the Linnean Society of London, Zoology, vol. 38, p. 157-211.

BEADLE, LC. 1974. The inland waters of tropical Africa. An introduction to tropical limnology. London: Longman. 365 p.

CALIJURI, MC. and DOS SANTOS, ACA. 2001. Temporal variation in phytoplankton primary production in a tropical reservoir (Barra Bonita, SP - Brazil). Hydrobiologia, vol. 445, p. 11-26. http:// dx.doi.org/10.1023/A:1017554829992

CALIJURI, MC., DEBERDT, GLB. and MINOTI, RT. 1999. A produtividade primária pelo fitoplâncton na represa de Salto Grande. In HENRY, R., ed. Ecologia de reservatórios: estrutura, funçáo e aspectos sociais. Botucatu: Fundibio/Fapesp. p. 109-148.

FERESIN, EG. 1994. Produção de carbono orgânico via fitoplâncton e bacterioplâncton em duas lagoas da planície de inundação do Rio Mogi-Guaçu (Estação Ecológica de Jataí, SP). São Carlos: Universidade Federal de São Carlos. [Tese de Doutorado].

FILETO, C. 2001. O zooplâncton do Lago Monte Alegre: variação temporal e a influência das fraçóes do fitoplâncton sobre o crescimento e reprodução de cladóceros. Ribeirão Preto: Universidade de São Paulo. [Dissertação de Mestrado]

FISHER, TR. 1979. Plankton and primary production in aquatic systems of the central Amazon basin. Journal 
of Comparative Biochemical and Physiology Part A: Physiology, vol. 621, p. 31-38.

GIANESELLA-GALVÃO, SMF. 1985. Primary production in ten reservoirs in southern Brazil. Hydrobiologia, vol. 122, p. 81-88. http://dx.doi. org/10.1007/BF00018962

GOLTERMAN, HL., CLYMO, RS. and OHNSTAD, MAM. 1978. Methods for physical and chemical analysis of freshwaters. 2nd ed. Oxford: Blackwell Scientific Publications. 213 p. IBP Handbook, no. 8.

HENRY, R. 1993. Primary production by phytoplankton and its controlling factors in Jurumirim Reservoir (SP, Brazil). Revista Brasileira de Biologia, vol. 53, p. 489-499.

HENRY, R., NOGUEIRA MG., POMPÊO, MLM. and MOSCHINI-CARLOS, V. 2006. Annual and short-term variability in primary productivity by phytoplankton correlated abiotic factors in the Jurumirim Reservoir (São Paulo, Brazil). Brazilian Journal of Biology, vol. 66, p. 239-261.

HENRY, R., NUNES, MA., MITSUKA, PM., LIMA, ND. and CASANOVA, SMC. 1998. Variação espacial e temporal da produtividade primária pelo fitoplâncton na Represa de Jurumirim (Rio Paranapanema, SP). Revista Brasileira de Biologia, vol. 58, p. 571-590. http://dx.doi.org/10.1590/ S0034-71081998000400005

HUBBLE, DS. and HARPER, DM. 2000. Top-down biological controls on tropical lake productivity. Lakes \& Reservoirs: Research and Management, vol. 5, p. 187-194. http://dx.doi.org/10.1046/j.14401770.2000.00112.x

JEFFREY, SW. and HUMPHREY, GF. 1975. New spectrophotometric equations for determining chlorophylls $a, b, c_{1}$ and $c_{2}$ in higher plants, algae and natural phytoplankton. Biochemical and Physiology Pflanzen, vol. 167, p. 191-194.

LEGRAND, C., RENGEFORS, K., FISTAROL, GO. and GRANELI, E. 2003. Allelopathy in phytoplankton-biochemical, ecological and evolutionary aspects. Phycologia, vol. 42, p. 406-419. http://dx.doi.org/10.2216/i0031-8884-42-4-406.1

LEWIS, WM. Jr. 1996. Tropical lakes: how latitude makes a difference. In SCHIEMER, F. and BOLAND, KT., ed. Perspectives in tropical limnology. Amsterdam: SPB Academic Publishing bv. p. 43-64.

LORENZEN, CJ. 1967. Determination of chlorophyll and phaeo-pigments: Spectrophotometric equations. Limnology and Oceanography, vol. 12, p. 343-346. http://dx.doi.org/10.4319/lo.1967.12.2.0343

MACKERETH, FJH., HERON, J. and TALLING, JF. 1978. Water analysis: some revised methods for limnologists. Cumbria and Dorser: Freshwater Biological Association. Scientific Publication, vol. 36.
NESTER, J. and WASSERMAN, W. 1974. Applied linear statistical models. Homewood, Illinois, USA: Richard D. Irwin.

NIMER, E. 1989. Climatologia do Brasil. 2. ed. Rio de Janeiro: IBGE. $421 \mathrm{p}$.

NISHIMURA, PY., MOSCHINI-CARLOS, V., POMPÊO, MLM., GIANESELLA, SMF and SALDANHA-CORRÊA, FMP. 2008. Phytoplankton primary productivity in Rio Grande and Taquacetuba branches (Billings Reservoir, São Paulo, Brazil). Verhandlungen der Internationale Vereinigung für Limnologie, vol. 30, no. 1, p. 50-52.

PADISÁK, J. and REYNOLDS, C. 2003. Shallow lakes: the absolute, the relative, the functional and the pragmatic. Hydrobiologia, vol. 506-509, p. 1-11. http://dx.doi.org/10.1023/ B:HYDR.0000008630.49527.29

PERES-NETO, PR., JACKSON, DA. and SOMERS, KM. 2003. Giving meaningful interpretation to ordination axes: assessing loading significance in principal component analysis. Ecology, vol. 84, p. 2347-2363.

PETRUCIO, MM. and BARBOSA, FAR. 2004. Diel variation of phytoplankton and bacterioplankton production rates in four tropical lakes in the middle Rio Doce basin (southeastern Brasil). Hydrobiologia, vol. 513, p. 71-76. http://dx.doi.org/10.1023/ B:hydr.0000018167.43745.33

PETRUCIO, MM., BARBOSA, FAR. and FURTADO, ALS. 2006. Bacterioplankton and phytoplankton production in seven lakes in the Middle Rio Doce basin, south-east Brazil. Limnologica, vol. 36, p. 192-203. http://dx.doi.org/10.1016/j. limno.2006.05.001

RAHAINGOMANANA, N., BARBOSA, FAR. and PETRUCIO, MM. 2002. Fractionated primary production of phytoplankton in lakes of the Rio Doce Valley (Southeastern Brazil). Verhandlungen der Internationale Vereinigung für Limnologie, vol. 28, p. 695-699.

REYNOLDS, CS. 1989. Physical determinants of phytoplankton succession. In SOMMER, U., ed. Plankton ecology. Succession in plankton communities. New York: Springer-Verlag. p. 9-56.

REYNOLDS, CS. 1997. Vegetation process in the pelagic: a model for ecosystem theory. In: KINE, O., ed. Excellence in ecology. Oldendorf: ECI. 371 p.

REYNOLDS, CS. 2006. Ecology of phytoplankton. Cambridge: Cambridge University Press. 535 p.

ROLAND, F. 2000. Produção primária fitoplanctônica. In BOZELLI, RL., ESTEVES, FA. and ROLAND, F., ed. Lago Batata: impacto e recuperaçáo de um ecossistema amazônico. Rio de Janeiro: IB-UFRJ/ SBL. p. 105-117.

ROLAND, F., ESTEVES, FA. and BARBOSA, FAR. 1997. The influence of the bauxite tailings on the 
light and its consequence on the phytoplankton primary production in an Amazonian floodplain lake. Internationale Vereinigung für Limnologie, vol. 26, p. 765-767.

RUTTNER, F. 1931. Hydrographische und hydrochemische Beobachtungen auf Java, Sumatra und Bali. Archiv für Hydrobiologie, Suppl. 8 (Tropische Binnengewässer 1), p. 197-454.

RUTTNER, F. 1952. Planktonstudien der Deutschen Limnogischen Sunda-Expedition. Archiv für Hydrobiologie, Suppl. 21 (Tropische Binnengewässer $10)$, p. 1-274.

SAS, H. 1989. Lake restoration by reduction of nutrient loadings. Expectations, experiences, extrapolations. Sankt Augustin: Academia Verlag Richarz Gmbb. $497 \mathrm{p}$.

SCHEFFER, M. 2004. Ecology of shallow lakes. Boston: Kluwer Academic Publishers. 357 p.

SCHMIDT, GW. 1973. Primary production of phytoplankton in the three types of Amazonian waters. III. Primary productivity of phytoplankton in a tropical flood-plain lake of central Amazonia, Lago do Castanho, Amazonas, Brazil. Amazoniana, vol. 4, p. 379-404.

SILVA, LHS. 2004. Fitoplancton de um pequeno reservatório eutrófico (Lago Monte Alegre, Ribeirão Preto, $S P)$ : dinâmica temporal e respostas à ação do zooplâncton e peixes. Rio de Janeiro: Universidade Federal do Rio de Janeiro. [Tese de Doutorado].

SOMMER, U. 1989. The role of competition for resources in phytoplankton succession. In: SOMMER, U., ed. Plankton ecology. Succession in plankton communities. New York: Springer-Verlag. p. 57-106.

SØNDERGAARD, M., JENSEN, JP. and JEPPESEN, E. 2003. Role of sediment and internal loading of phosphorus in shallow lakes. Hydrobiologia, vol. 506-509, p. 135-145. http://dx.doi.org/10.1023/ B:HYDR.0000008611.12704.dd

STERNER, RW. 1989. The role of grazers in phytoplankton succession. In: SOMMER, U., ed. Plankton ecology. Succession in plankton communities. New York: Springer-Verlag. p. 107-170.

STUMM, W. and MORGAN, JP. 1996. Aquatic chemistry. 3rd ed. New York: Wiley-Interscience. 1022 p.
TALLING, JF. and LEMOALLE, J. 1998. Ecological dynamics of tropical inland waters. Cambridge: Cambridge University Press. 441 p.

TOLEDO, LG. and HAY, OD. 1988. Variação sazonal da produção primária do fitoplâncton e dos fatores limnológicos do Lago do Paranoá, Brasília, DF. Acta Limnologica Brasiliensia, vol. 2, p. 347-365.

TUNDISI, JG. and MATSUMURA-TUNDISI, T. 2008. Limnologia. São Paulo: Oficina dos Textos. $631 \mathrm{p}$.

TUNDISI, JG., MATSUMURA-TUNDISI, T. and CALIJURI, MC. 1993. Limnology and management of reservoirs in Brazil. In STRASKRABA, M., TUNDISI, JG. and DUNCAN, A., eds. Comparative reservoir limnology and water quality management. Dordrecht: Academic Publishers. p. 25-55.

TUNDISI, JG., MATSUMURA-TUNDISI, T., PONTES, MCF. and GENTIL, JG. 1981. Limnological studies of Quaternary Lakes in Eastern Brazil. I. Primary production of phytoplankton and ecological factors at Lake D. Helvécio. Revista Brasileira de Botânica, vol. 4, p. 5-14.

TUNDISI, JG., SAIJO, Y., HENRY, R. and NAKAMOTO, N. 1997. Primary productivity, phytoplankton biomass and light photosyntesis responses in four lakes. In TUNDISI, JG. and SAIJO, Y., ed. Limnological sudies on the Rio Doce Valley lakes, Brazil. São Carlos: Brazilian Academy of Sciences. p. 199-225.

VAN DONK, E. 1989. The role of fungal parasites in phytoplankton succession. In SOMMER, U., ed. Plankton ecology. Succession in plankton communities. New York: Springer-Verlag. p. 171-194.

VANNI, MJ. and LAYNE, CD. 1997. Nutrient recycling and herbivory as mechanisms in the "top-down" effect of fish on algae in lakes. Ecology, vol. 78, p. 21-40.

WETZEL, RG. and LIKENS, GE. 1991. Limnological analyses. 2nd ed. New York: Springer Verlag. 391 p.

WORTHINGTON, EB. 1931. Vertical movements of fresh-water macroplankton. Internationale Revue der gesamten Hydrobiologie, vol. 25, p. 394-436. http:// dx.doi.org/10.1002/iroh.19310250510

WORTHINGTON, EB. and RICARDO, CK. 1936. Scientific results of the Cambridge Expedition to the East African lakes, 1930-1. The vertical distribution and movements of the plankton in Lakes Rudolf, Naivasha, Edward and Bunyoni. Journal of the Linnean Society of London, Zoology, vol. 40, p. 33-69. 